\title{
RITUALS AROUND SUDDEN DEATH IN RECENT YEARS
}

\author{
Anders Gustavsson
}

\begin{abstract}
Life is normally expected to proceed through childhood, youth, adulthood and old age. What happens then if death occurs at some earlier phase of life and not at a far distant time in people's everyday lives? This will most often be a sudden and unexpected death. How do the nearest family, friends and acquaintances of the deceased cope with this? How and why are new rituals created, how are they spread, and what meaning do they have for the people who are thrust into difficult situations? These are the questions that will be discussed in this paper. The emphasis is on the present day.

The public marking of sudden death by means of collective actions has become far more prominent in recent years in comparison to the past times. This can be seen at sites where a traffic accident, a murder, or manslaughter has occurred, and in connection with memorials to fishermen who have lost their lives at sea.

A behavioural pattern having mostly to do with young people who have perished or been killed has obviously been the subject of fairly rapid cultivation. A generational gap is obvious in such incidents. The youth thus become the centre of attention in that they are the most active and inventive.

There is no doubt that newspapers have been instrumental in the spread of these new rituals that commemorate young victims of unexpected death, with their articles and, especially, their photographs from the scenes of traffic accidents or murders. The newspapers' clearly increasing interest in life's tragic occurrences has led to a noticeable change in attitude that indicates that such tragedy no longer must be kept secret. Instead, it can be commemorated more openly in public and within one's social group. Solidarity and collectivism have become important key words in traumatic situations at the expense of individuality and privacy. This is a primary change in the study of rituals around sudden death in recent times.
\end{abstract}

Key words: anniversary, grief on the Internet, journalists, memorials, murders, newspaper reports, patterns of behavior, public grief, rituals, solidarity, sudden death, traffic accidents, youth

The life of every human being extends from birth to death. Death can sometimes accompany birth when an expected child is stillborn or miscarried earlier in pregnancy. In all other cases, life is expected to proceed through childhood, youth, adulthood and old age. In former times, this process was illustrated in mass-produced pictures showing the successive ages of a woman and 
a man (e. g., Bringéus 1988). Life reached its end with death after a person had become aged and infirm. Even though average life expectancy has risen markedly during the past decades, death still marks the end. No one can escape this fate even if death has often been said to have become subject to taboo in recent years, and has become marginalized in people's social lives. This concurs with the argumentation given by the French historian Phillippe Ariès (1978). The idea of such marginalization has, however, been criticized by other scholars, such as the Swedish ethnologist Lynn Åkesson (1997). The English sociologist Zygmunt Bauman (1994) argues that human beings strive for immortality in different ways. Death will be more easily shoved aside as relating to a date in distant future when the individual will have become old and frail, and perhaps even resided for a time in an institution for the care of the aged.

What happens then if death occurs at an earlier phase of life and not at a far distant time? Most often, this will be a sudden and unexpected death. How do the nearest family, friends and acquaintances of the deceased cope with this? How and why are new rituals created, how are they spread, and what meaning do they have for those people who are thrust into difficult situations? These are questions that will be discussed in this paper. The emphasis is on the present day.

Ritual presupposes the performance of actions and the repeating and carrying out of these actions in a public social context (e.g., Klein 1995). The actions also have a deeper symbolic meaning for the participants.

The fieldwork for this study, consisting of interviews, observations and photography, was carried out in southeastern Norway and in the province of Bohuslän in western Sweden. Articles in Norwegian and Swedish newspapers have also been important sources.

\section{LOSS OF LIFE AT SEA}

Being dependent on one's income from working at the open sea must be associated with obvious dangers of shipwreck and death by drowning. This became only too evident in the coastal villages of the western coast of Sweden when extensive deep-sea fishing started in the 1860s. Fishing boats were powered by sail until being equipped with engines in the $1890 \mathrm{~s}$. This improvement led to a reduction in the risk of accidents. The 1880 s were especially plagued by accidents. During the 1900s, the two world wars also meant great risk for people living along the coast because shipwrecks could be caused by the explosion of submerged mines. 
Psychologically speaking, it was felt to be an even greater tragedy if the dead were not buried in consecrated ground. In this case, the next-of-kin, widows, mothers and children, had no place on which to focus their grief and no grave to tend. In addition, popular superstition held that bodies not buried in consecrated ground could become ghosts and be a danger to the living if met unexpectedly (af Klintberg 1973; Pentikäinen 1974). Nor was it possible to hold a funeral service if the body had not been found. The popular term used along Sweden's west coast was that the drowned men were "lost".

Anxiety regarding shipwreck was naturally very prevalent among the fishermen's wives. In addition to the mental shock and grief, the loss of the family's breadwinner would devastate the basis of the household's economy. Having to live with the constant fear meant that a tight social relationship between the women was vital. Their ability to console and support each other was of immense importance when one of them, or as it happened only too often, several women in the same village had lost a husband and one or more sons. Before the day of the telephone and telegraph, men arriving home and sailing into their home port would show grief and bereavement by lowering their ship's sails if one or more of the crew had been lost. The men, however, were forced to go out to sea in their boats even in the combat conditions of the two world wars (Åberg \& Edvardsson 1985). On being interviewed, the fishermen stated that they had no other choice because of the need to sustain their families. They could still feel that their women were in an even more difficult situation in that they lived with constant uncertainty. The men, on the other hand, in the midst of the reality of the sea, were completely engrossed in their work. Under such circumstances, they had little time to spend worrying about possible accidents.

Religion frequently became a source of comfort and refuge for the anxious and sorrowing women. One fisherman's wife, from the island of Öckerö near Gothenburg, who had lost two young sons when their boat hit a submerged mine, told of her reaction on learning of the disaster:

... went home and sat down all alone. And then something odd happened. A bible verse that I had repeated time and time again entered my mind, "Thy heart shall not be troubled nor forlorn..." (Åberg \& Edvardsson 1985: 100)

Shipwrecks at sea have sometimes provided a psychological basis for religious revivals in a locality. This can occur when charismatic revivalist preachers have come to a coastal village in connection with terrible disasters. The preachers' sermonizing served to remind the local people of eternity that had been made relevant by the deaths due to shipwreck (Gustavsson 1984: 32ff). 
When the widows of these drowned fishermen eventually died, often many years later, they were buried in single graves in the churchyard provided they had not re-married. The epitaph on the gravestone simply used the word "Wife" without any mention of the husband's name. The woman's status as a widow has been marked on gravestones in later years. An inscription on a gravestone in Mollösund Cemetery, for a woman who died in 1966, reads that she was the Widow of Joakim Patriksson who died in the shipwreck of the Orion in 1924. A woman from Sydkoster had been a widow for even longer, as can be seen from the inscription on her gravestone from 1992: Wife of Axel Antonsson who drowned in Koster Fjord in 1934.

Many years after local families had experienced these terrible disasters, the idea of raising a common memorial stone in the cemetery began to be discussed in some villages along the coast of Bohuslän. The names of all those lost at sea since the start of deep-sea fishing were to be inscribed in chronological order while their ages were also given in many cases. This has made it possible to determine the number of young and middle-aged men from the various coastal villages who had lost their lives at sea, and to see that many died at about the same time. The dominant position of the 19 th century as to the number of deaths can be seen, for example, on the memorial in BohusMalmön. 38 out of a total of 48 men drowned during the second half of the 1800 s.

The memorials were raised to ensure that the names of the dead would never be forgotten and also that they would always have a place in local history even if their final resting place lay at the bottom of the sea. The earliest recorded memorial stones of this kind were put up in the 1950s, such as those in Gullholmen in 1952 and Åstol in 1958. Soon afterwards, stones were erected in Rönnäng in 1960 and Kungshamn in 1965. The initiative in these cases was taken by the local fishermen themselves. The stone in Kungshamn is inscribed to that effect: Kungshamn's fishermen put up this stone in the year 1965. It was in these years, particularly in the 1960s, that extensive deep-sea fishing came to an end in the villages of Bohuslän.

There were, however, still many coastal villages without memorials in the 1990s. Several were erected in different places within a short period of time. Much of the local populace rapidly became interested in making oral tradition about the disasters tangible and visible. Such memorials were put up in BohusMalmön and Käringön in 1993, followed by Mollösund and Bovallstrand in 1994 and Öckerö in 1998. The newest memorials recorded are those erected in Resö in 2000 and Lyse in 2002 (Fig. 1). Local newspapers showed great interest in these events, printing long articles about the reasons for raising the various 
Figure 1. The memorial stone erected in 2002 in Lyse cemetery in commemoration of fishermen and mariners who were lost at sea during 1876-1908 and 1909-1950. Photo by Anders Gustavsson.

memorials and their dedications. Such articles have given other local communities an incentive to erect new memorials. Many of these latest memorials have been put up through the efforts of local historical societies. This is due to a wish to emphasize the importance that the dead men had in local history despite their not having been buried in their home ground. They would no longer remain anonymous, but were at

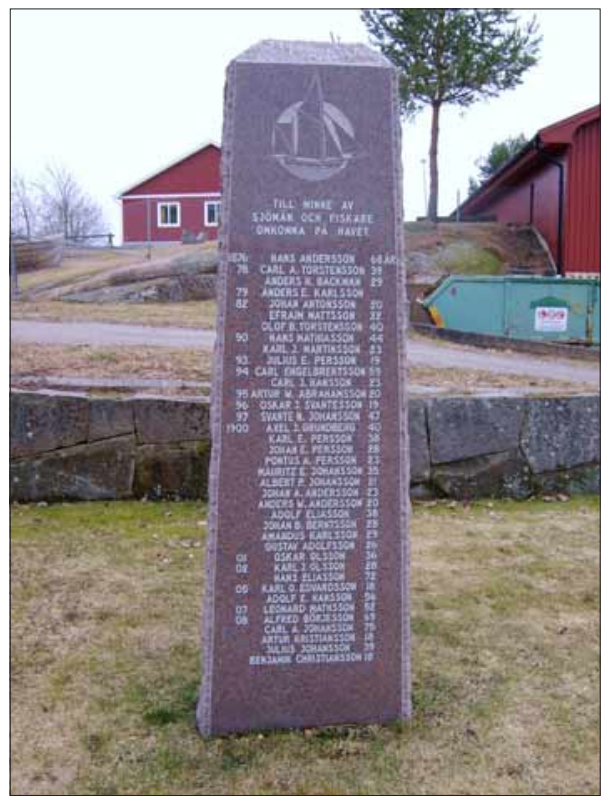
last to be visibly remembered and honoured for their work at sea on behalf of home communities. On Käringön, a total of 157 men were honoured. After the ceremony in 1993, one of the older wives of island fishermen, who had been instrumental in raising the memorial, said

[i]t was a moving experience to see that memorial for all those who did not return. Now they have come home at last... There were tragedies connected to each and every name. My own forefathers were lost at sea. That was something every single family on Käringön experienced. Now everyone has a place to visit (Bohusläningen 1993).

Extensive archival research has been carried out by enthusiastic local historians to ensure the inclusion of every possible name on the stone so that none would be forgotten. Oral tradition was not sufficient in this reconstruction of the shipwrecks that had occurred in the latter part of the 1800s. At the time of the consecration ceremony for the Mollösund memorial in the summer of 1994, the newspaper Bohusläningen reported, Majken Rohdén has completed the weighty task of finding all the names of the deceased. She has also made a list of all their next-of-kin (Bohusläningen 1994). The inscription on the Mollösund memorial reads: Storm and strife gave them a grave at sea. Below the inscription are listed the names of the 48 men who died at sea between 1861 and 1994. That last date marks the drowing of a man in the sinking of ferry MS Estonia on the Baltic Sea. 


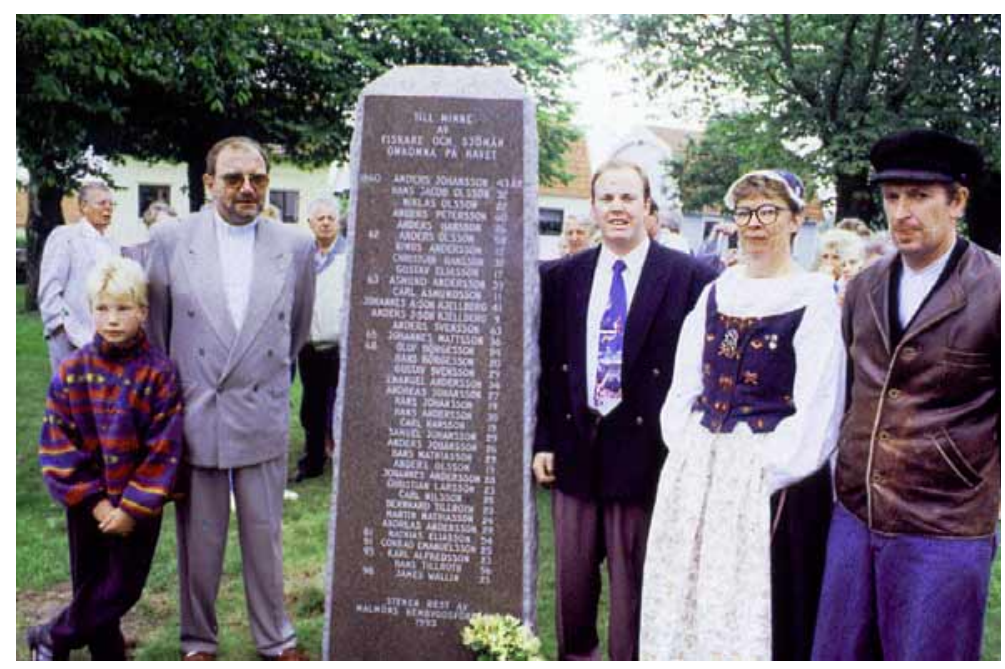

Figure 2. The consecration ceremony in Bohus-Malmön in 1993 carried out by a clergyman with the participation of many local inhabitants. Photo from Bohusläningen 1993, Uddevalla.

The dedication ceremonies have been conducted by clergymen with the participation of local historians, former fishermen and seamen (Fig. 2). The names of all the dead victims are read out and a wreath placed in front of the memorial. The clergymen's participation has given a spiritual dimension to the ceremony similar to that taking place at an ordinary funeral service, something that those who died at sea had never benefitted from. A great many local inhabitants, both old and young, men and women, have been present at these ceremonies as has been reported in regional newspapers. About two hundred people attended the ceremony at Lyse near Lysekil in 2002 (Bohusläningen 2002). The memorial consequently becomes a communal concern of interest to the entire local populace. Many local people have relatives among these longdead victims.

The memorial stones have given the local history a new dimension in present times. Memories that were formerly found only in oral narrative tradition, have now received a tangible, physical shape. Such tradition is in grave danger of becoming diluted and eventually disappearing. In this situation, history has been revitalized by means of the newly erected memorial stones, the sturdy quality of which bodes well for the future. If and when a new death occurs at sea, the victim's name will be inscribed on the stone and thus find its place in a historical relationship with the local society.

As a comparison with the coastal areas and fisheries of northern Norway, one might mention the book written by the historian Narve Fulsås (2003) from 
Troms $\varnothing$ about the sea, death at sea and weather conditions in the period 18501950. In this book he has carefully documented the making of a memorial stone erected in 1950 in memory of fishermen who drowned in the Lofoten fisheries. This is actually older than the oldest stone in Bohuslän, namely the one from 1952 on Gullholmen. The inscription on the stone in Lofoten reads, In memory of fishermen lost on the Lofoten Sea. No names or years are mentioned, and in this way the stone becomes a common memorial in contrast to those along the coast of Bohuslän (see Map). The anonymity of the dead men is accentuated in that it is only by means of personal names and dates that the individual makes its presence felt. In Bohuslän, there are very few instances

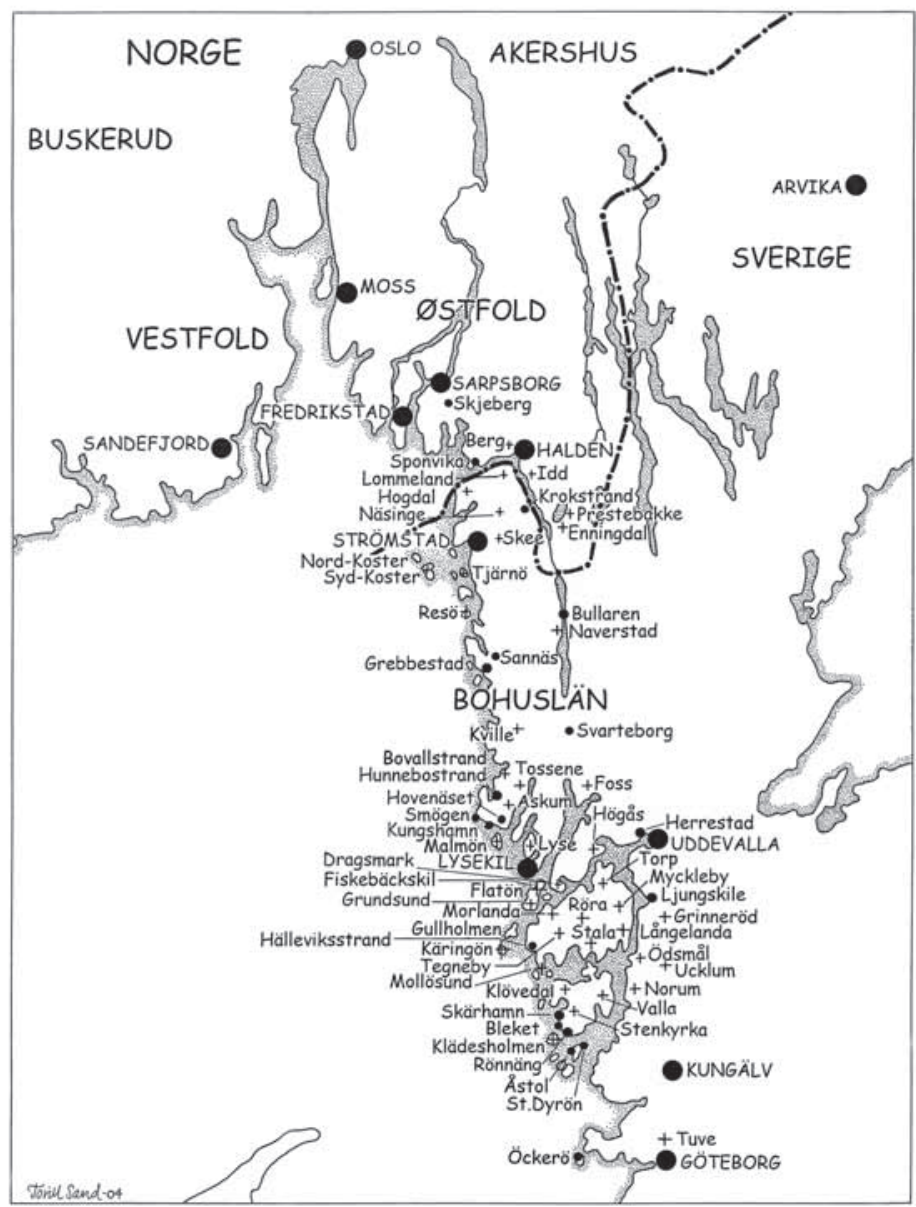

Map. Memorials along the coast of Bohuslän 
where names and dates are not listed on memorial stones. Since Fulsås concluded his study in 1950, no stone raised after this year has received mention in his book.

In addition to the memorial stones, a new and recent trend in the WestSwedish area under investigation has been the holding of a memorial service in the parish church if the body or bodies of victims have not been recovered from a shipwreck at sea. One such service took place in Morlanda Church in 2000 in memory of a lone fisherman. The traditional funeral rites must be adjusted to account for the absence of a coffin in the church. The next of kin and the circle of friends and acquaintances are thus given an opportunity for a farewell ceremony that was unknown previously. Their grief and bereavement can have a more explicit and collective expression. After a ceremony of this kind the name of the deceased is inscribed on the memorial stone in token of future remembrance. Local newspapers report on such events and these may arouse widespread local interest. The newspaper Göteborgs Posten used the headline "The entire countryside mourns the crew" when reporting on a memorial service in Kville Church. This took place after the sudden disappearance of the fishing boat Novi with her crew of four during lobster fishing in September of 1995 . Nearly all 1,800 seats in the church were filled, indicating broad local involvement in this farewell to the dead. This particular ceremony included memorial speeches, the lighting of candles and recitation of poetry, that is to say, both personal actions and words (Göteborgs Posten 1996).

\section{DEATH DUE TO TRAFFIC ACCIDENTS}

The sea is not the only one to reap accident victims. These tragedies also occur on highways because of the marked growth in automotive traffic in the 1900s. The difference between accidents at sea and those in traffic is that the scene of an accident on a highway can be determined. The ethnologist Konrad Köstlin has studied the increasing number of roadside memorials - crosses placed along German highways - at the scenes of fatal accidents during the 1990s (Köstlin 1999). The site then has a kind of sacred meaning for passers-by because a fatal accident has taken place there, and it also serves as a reminder to drive safely. The crosses then will have a preventive function. General religious and secular meanings can thus go hand-in-hand in contemporary society.

Roadside memorials of this kind have also become to be found in Norway and Sweden in later years. A cross decorated with flowers can be placed at a spot alongside the road where an accident has occurred. However, a wooden 
Figure 3. A wooden cross in Stala that was put up after an accident at a sharp bend in the road in 1997. Photo by Anders Gustavsson (2004).

cross that I photographed after an accident in Hälleviksstrand in Orust Municipality, Bohuslän in January 1998, disappeared after a period of about three months. Another cross in Stala, in Orust, that was set up after an accident at a sharp bend in the road in October 1997 still stands and is regularly decorated with plastic flowers (Fig. 3). This cross is very conspicuous and easily observable. The memory of a fatal accident and a warning of the dangers

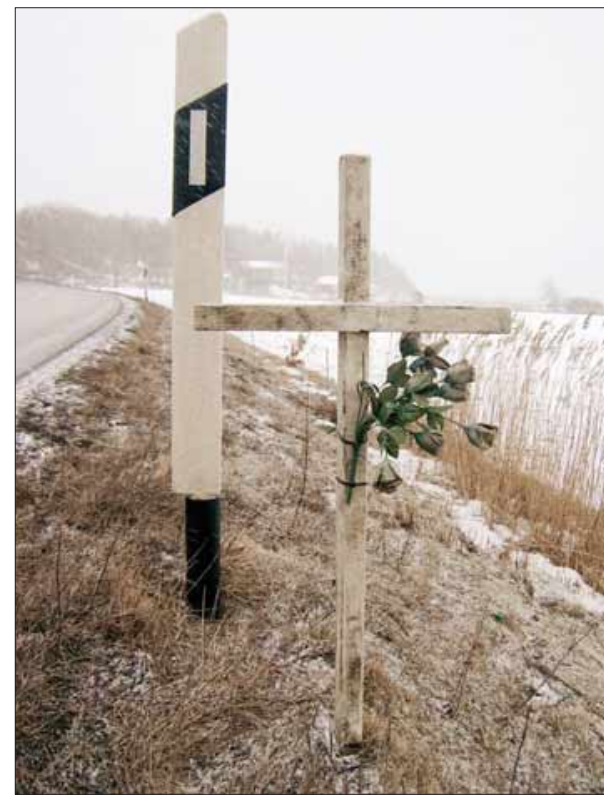
in traffic are indeed combined in this example. The cross therefore will retain its significance for wayfarers in years to come, not just in the months immediately following the accident.

The fact that a memorial marking can remain to be cared for over a long period of time may be of actual benefit to the next of kin. This was confirmed by a married couple in a newspaper interview in 2003. They had lost their son in 1995 when he was run down by an inebriated driver. The parents have cared for a bed of plants encircled by stones at the scene of the accident. The father stated

[v]isiting the grave is just too sorrowful, so I do not do that more often than twice a year. This memorial does not arouse the same feelings and I also feel I am doing something meaningful about drunk driving (Kyrkans Tidning 2003).

The accident site is here experienced both as being less personal than the grave and as giving society at large, not only a private circle, an opportunity for action, in this case, warning against drunk driving. This effort is made to save others from suffering the same kind of tragedy as oneself.

A memorial made of stone cannot be placed as close to the road itself and is, accordingly, not as visible as a wooden cross, but it is, on the other hand, far more durable than a cross of wood. After comedian Lasse Lindroth was killed in 1999 in an accident at a very sharp curve in Bohuslän when driving home 
from Oslo to Gothenburg, his relatives placed a memorial stone on the site. The inscription on the stone reads, Lasse Lindroth died here on 11 July 1999. Use of the personal name ensures that the victim will remain an individual for all time in contrast to the anonymous wooden crosses. Many friends and acquaintances have participated in the consecration ceremonies of such memorial stones, especially when the victim lived near the accident site. The ceremony thus becomes a local manifestation of memory and solidarity.

The National Association for the Victims of Traffic Accidents, Hordaland in Norway planned to place signs marked with crosses at sites of fatal accidents along highways throughout Norway. These white crosses against a black background were meant to symbolize death. According to the association, they would warn about the continuously rising number of fatal traffic accidents and thus help to save lives. The cross as a symbol of death would, in this case, act as a deterrent. The Norwegian transport authorities did not, however, give permission for the plan. Instead, they saw the crosses as a danger for traffic safety because of their distracting drivers' attention (Aftenposten 2000b). Individuals and associations cannot act freely as far as public places are concerned. There are official, legal limits as to what can be realized as a collective memorial action.

An illegal action was carried out in Norway in the autumn of 2003 when 58 wooden crosses were set up along highway E6 in Østfold as a reminder of the 58 persons who had been killed on this highway since 1990. After an hour, the activists were forced by the police to remove the crosses (Halden Arbeiderblad 2003). The 58 victims were not regarded as individuals, but were remembered as a collective unit. The reason for setting up the crosses was once again to warn of the danger of new accidents. The activists also hoped that their demonstration would help to hasten the building of a new four-lane highway. Thus, a criticism of the Norwegian transport authorities, and of the state, was involved in the action.

In recent years, a new form of remembrance has rapidly gained popularity in Sweden - at accident sites crosses have been replaced by brighter symbols, such as flowers, lighted candles, poems and photos of the victim or victims. Such items do not have anything approaching the durability of wooden crosses or stones. The new symbols have a more spontaneous character as an expression of the sudden grief and bereavement brought on by an accident. Such brighter symbols, however, will help to lighten the bleakness of the shock that has been experienced. The cross is more linked with death and sorrow in modern Swedish society, and to the darker side of existence in general. Brighter symbols may fill a need for support in the severe situation of grief. Flowers 
when they have wilted and gone out candles have in several cases been replaced. This, however, demands repeated actions from the next of kin and friends of the victims. A similar change, replacement of the cross with flowers and candles, has been recorded in obituaries and gravestones in recent years (Dahlgren 2000, Gustavsson 2003).

Friends of the victim(s) have also started to assemble in person at the scene of an accident shortly after it has taken place in order to give silent and collective testimony of their grief and bereavement. This is especially true when the accidents involve young people. The disaster will be experienced as being particularly tangible on the precise site of the accident. Several instances of this new custom have been reported in articles and photographs in both Norwegian and Swedish newspapers. In 2003, a newspaper reporter from Oslo told of having been sent out to photograph several such incidents during the last years.

I had the opportunity to conduct a documentation of a memorial event in Morlanda on the island of Orust in September 2000. A seventeen-year-old boy from Västra Frölunda, a suburb of Gothenburg, crashed his car one night on a

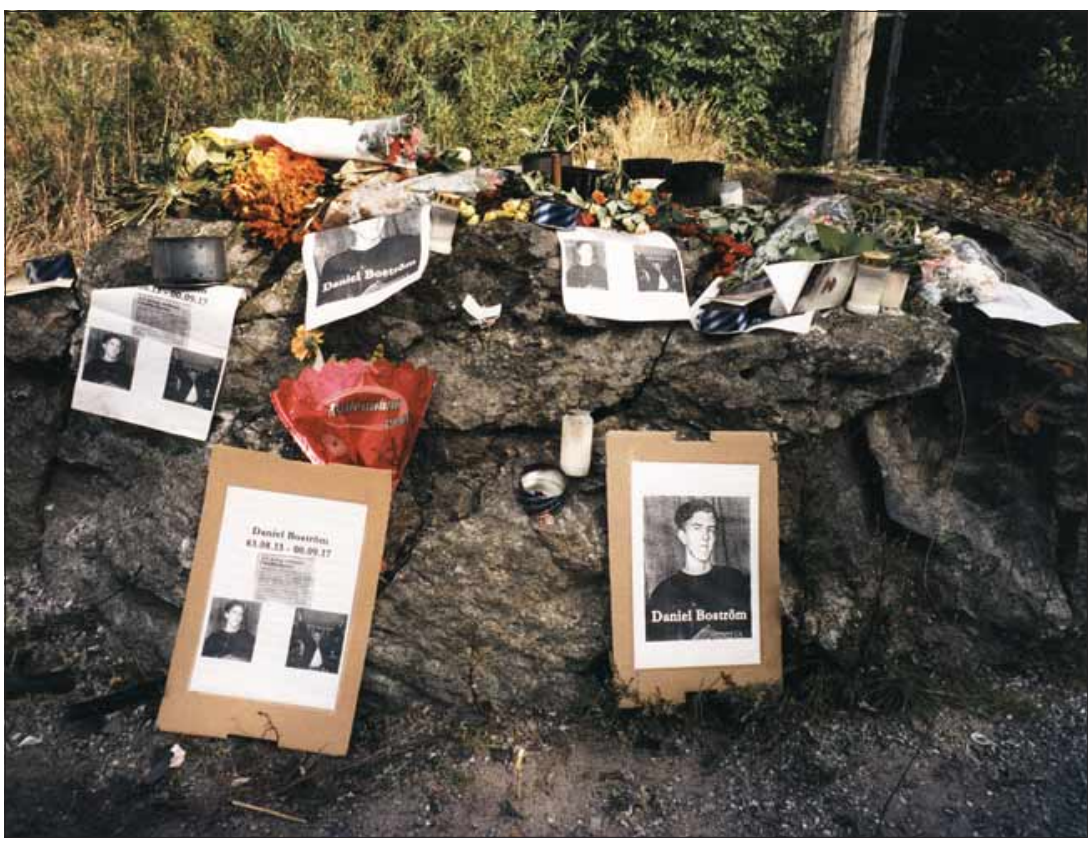

Figure 4. A 17-year-old boy from Västra Frölunda in Gothenburg lost his life after crashing his car in this mountainside in September 2000. The next evening his young friends gathered at the site and placed there several photographs of the victim, flowers and numerous lighted candles and torches. Photo by Anders Gustavsson. 
rocky cliff and was instantly killed. The next evening a large group of darkclad young people assembled at the scene of the accident about 80 kilometres from Gothenburg. There, the young people lit candles and set out flowers and several enlarged photographs of the victim (Fig. 4). The photos especially strengthened the impression that the victim could be felt as being present. The young people remained at the site in heartfelt silence for a long time. I observed all of this at a tactful distance and later photographed the richly adorned site. However, within a few weeks this memorial had disappeared; the flowers had withered and the candles burned out. The idea of using the site as a symbol of warning had not been the objective here, as it had been in previous instances of wooden crosses being placed alongside highways. After the funeral, the next of kin and the young friends could visit the grave whenever they wished to commemorate the victim, and had no need to drive to an accident site a long distance away.

Traffic authorities in Sweden have reacted with unease to the new custom of the gathering of large groups of people at accident sites. A representative for the Highway Department in western Sweden stated in 1999

$[\mathrm{w}]$ hen these people gather together after an incident like this, they just don't consider their own safety. We have had several close calls recently and fear that this may lead to a serious accident (Göteborgs Posten 1999a).

The same traffic accident may often involve the deaths of several young people. I have found quite a number of newspaper reports from Norway in recent years showing how an entire community is stricken when the young victims come from the same area. This leads to acute despair involving the entire community just as was the case when several fishermen from the same village were lost (see above). After a traffic accident in February 2000 in Norway in which three young people were killed, a man who lives in the stricken community of some 500 people said, [i] n a tiny village like ours, we all feel like the next of kin (VG 2000) (Fig. 5). The scenes of such traffic accidents and the young people's homes are often located close to each other, since the victims have been on their way to or from some social gathering nearby. Grief can be expressed by coming together both at the scene of the accident and in available village meeting places such as the church, the community centre or a clubhouse. Gatherings of this kind are held immediately after the accident and may entail talks and the lighting of candles and, occasionally, a display of photographs of the victims. Crowds of people have shown their sympathy at such times of grief by coming together both outdoors and indoors. The solidarity of the local community is very strong in such critical situations and is experi- 


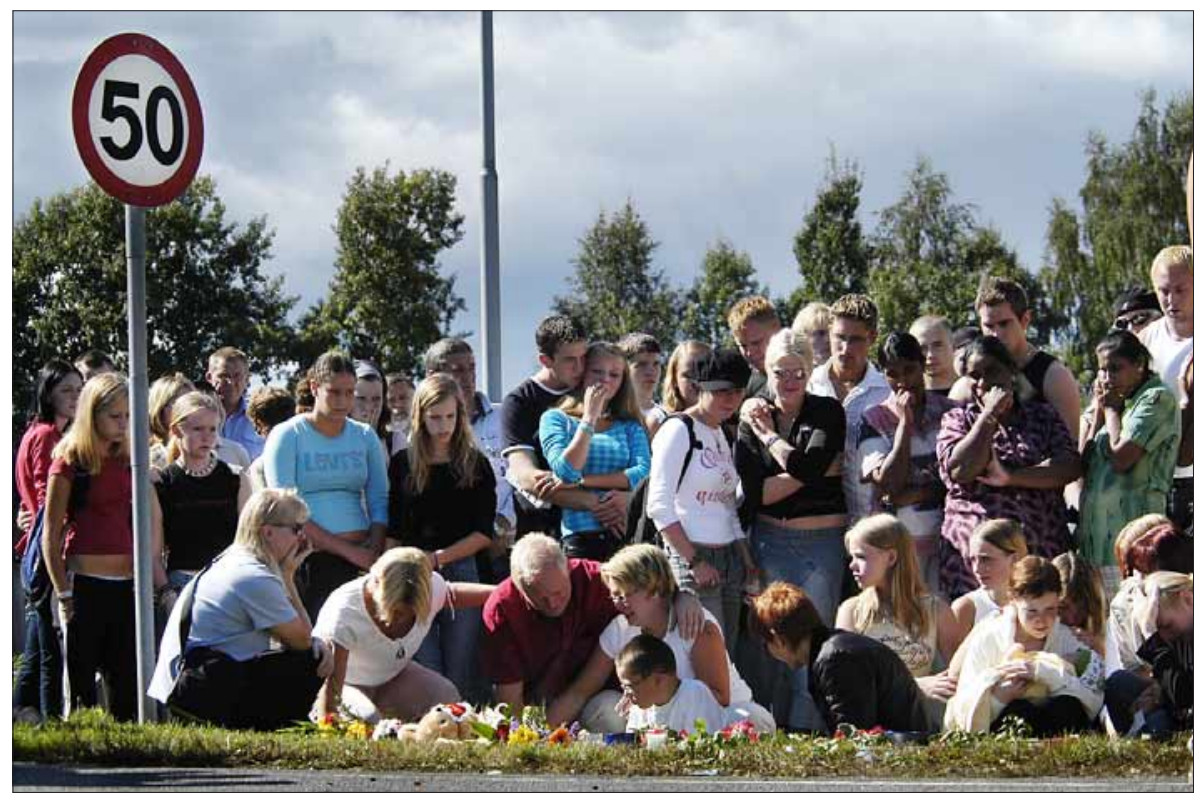

Figure 5. About 150 young people assembled at the scene of a traffic accident in 2003 near Oslo on the day after three local youngsters died after colliding with a bus. Photo by Jon Terje H. Hansen, Dagbladet, Oslo.

enced as being communal. Over 500 young people took part in a memorial service in Randaberg Church in 2000 after three local young people had been killed due to crashing into a tunnel wall. Photographs of the victims and lighted candles were placed at the entrance of the church (Aftenposten 2000a). It helped us all when we saw that almost the entire community was present, said the local sheriff when nearly 300 people gathered in Eggedal's community centre in Buskerud county after two young men were killed in 2002 when their car crashed into a building (Dagbladet 2002b). In addition, a huge crowd of people cannot gather together on a highway of heavy traffic after a fatal accident, but must find some other and larger venue for holding the memorial ceremony.

Young people have recently started to adopt a completely new way of expressing their grief and sense of loss when close friends have lost their lives they publish written messages on the Internet. This method serves to supplement the visits to the place of accident. When a fifteen-year-old girl from Bærum near Oslo was killed while riding her bicycle in October of 2004, her close friends immediately established a website entitled Guestbook at www.johannerip.com. The site features not only all the different messages written by friends and relatives, but also messages from many people from outside the closest 
circle of friends. This is our way of showing our grief. We think it's just fine that anyone can find out what we feel. We are also happy that people we don't know show that they care about this, said a couple of close girlfriends who were responsible for the website. One recurring theme was that the deceased was an angel, for example, Johanne was an angel who was sent to Earth to teach others how to laugh and smile. But God needed her in Heaven or You will always be an angel in my eyes! Rest in peace, we'll meet again! This form of belief in angels can be associated with neoreligious trends (see below). The parents of the deceased have also derived comfort from acquainting themselves with the messages posted on the website. I feel that taking part in the website helps me to keep going, the father of a deceased has put it (Aftenposten 2001). It makes my griefless lonely (VG 2004). Another website was set up by a young man from Bergen whose best friend was killed in a traffic accident. According to him, the purpose of this site is to help others who mourn the loss of a young person they loved (www.viminner.no).

Through the mediation of Internet, young people can sit in their own rooms and write down their innermost thoughts without having to physically move to a particular place. This encourages individual expression of mourning, while the collective and official aspect is invoked when both the close circle of friends and the general public are able to read the messages that have been published at the website. The young people are able to express them repeatedly as if they were carrying on a dialogue with the deceased friend. All of this indicates our witnessing a form of ritual behaviour. Intense emotions can be more easily expressed by young people in written form when sitting alone in front of their PCs rather than orally when confronted by a gathering of friends and acquaintances at the location of a physical memorial. The use of the Internet and gathering together at such memorial places do not exclude one another, though, but serve different functions for the mourners.

\section{MURDER OR MANSLAUGHTER IN PUBLIC AREAS}

The murder of Sweden's Prime Minister, Olof Palme, on a city street in Stockholm in 1986 was an immense shock for the Swedish people. This was expressed in numerous ritual demonstrations. Enormous quantities of flowers, candles and hand-written tributes were laid at the murder site. These activities have been described by the German ethnologist Martin Scharfe who was a guest professor in Stockholm at the time. His explanation of the causes of such vast collective actions was that they were especially indicative of a crisis in the 
national consciousness. The general public experienced the murder of Prime Minister as a threat to the nation (Scharfe 1989).

Several newspapers in both Norway and Sweden have reported in recent years about similar expressions of grief and remembrance at murder sites. If the murder has taken place indoors, such observances are carried out outside the building so that more people can participate in the actions expressing sorrow and disgust. When a man was found murdered in his apartment in Forsbacka in Gästrikland in December of 2003, newspaper Aftonbladet reported shortly afterwards that his friends have made a huge memorial outside the apartment block, consisting of candles, flowers and personal greetings (Aftonbladet 2003). They also expressed uneasiness and fear because of the possible presence of an unknown murderer in their neighbourhood. You don't feel safe outdoors any more, as one of the man's friends said. The above cases concerned a completely ordinary person who was the victim of a murder.

The murder of Sweden's foreign minister Anna Lindh on 10 September 2003 received special attention in the media. A large photograph of Lindh, surrounded by flowers and lit candles, was placed outside the department store in Stockholm where she was stabbed. The murder of Sabina, a little five-yearold girl from Arvika, Värmland, who was stabbed by a psychiatric patient the day after Anna Lindh's murder, also received vast attention in Sweden's national newspapers. Scores of children have placed toys, flowers and drawings for Sabina at the scene of her murder, reported Göteborgs Tidningen and published several photographs of the objects (Göteborgs Tidningen 2003). A large photograph of Sabina was hung on the fence surrounding her day-care centre. In many of the greetings by children and adults, angels were mentioned. The angels are guarding you, Sabina, wrote Rebecca and Anki. As was expressed by one mourner, Sabina was seen as having moved on to a life among angels: Little Sabina, play with other angel children. This indicates a need and desire to emphasize continuation beyond the limits of earthly life when a child dies. The brutal and sudden obliteration of a fragile, budding life will otherwise make the parting even more tragic and definite. A belief in an affirmative continuation of existence after death can obviously help in the traumatic grief process. The dead child has not only come to the angels, but is also considered to have become an angelchild. This is consistent with a neoreligious conception of existence (Dahlgren 2000), and has also been reinforced by neoreligious movements (Alver 1999).

Such ways of thinking can also be encountered on the memorial websites that have been established when children or young people have been victims of murder. I hope you're happy in Heaven and that you're keeping an eye on us 
from up there - lots of love from Micke, was one of the messages published on the website Lunarstorm after the murder of a twenty-year-old girl in Sala, Sweden, in 2005 (Göteborgs Tidningen 2005). Another friend wrote, [s]ee you in Heaven. The conceptions in messages of this kind often have to do with a belief in the victim's residing in Heaven and watching over the life on Earth. The mourners and the victim are expected to meet again in some unforeseeable future. This indicates the obvious influence of neoreligious trends which specifically stress the importance of both individuals and a bright and harmonious view of paradise (Alver 1996).

Ritual expression is felt to be necessary not only at the scene of a murder but also in the public sphere where many people can gather together, as has been shown in connection with deaths due to traffic accidents (see above). In the public space, people can experience solidarity and give collective expression to their grief and protest against the traumatic situation that has arisen. On the evening after Sabina's murder in Arvika, more than 2,000 people came together in the town square to take part in a memorial ceremony for both Sweden's foreign minister and for little Sabina. Here no distinction was made as to social class or age. Death obliterates all social stratification. The mes-

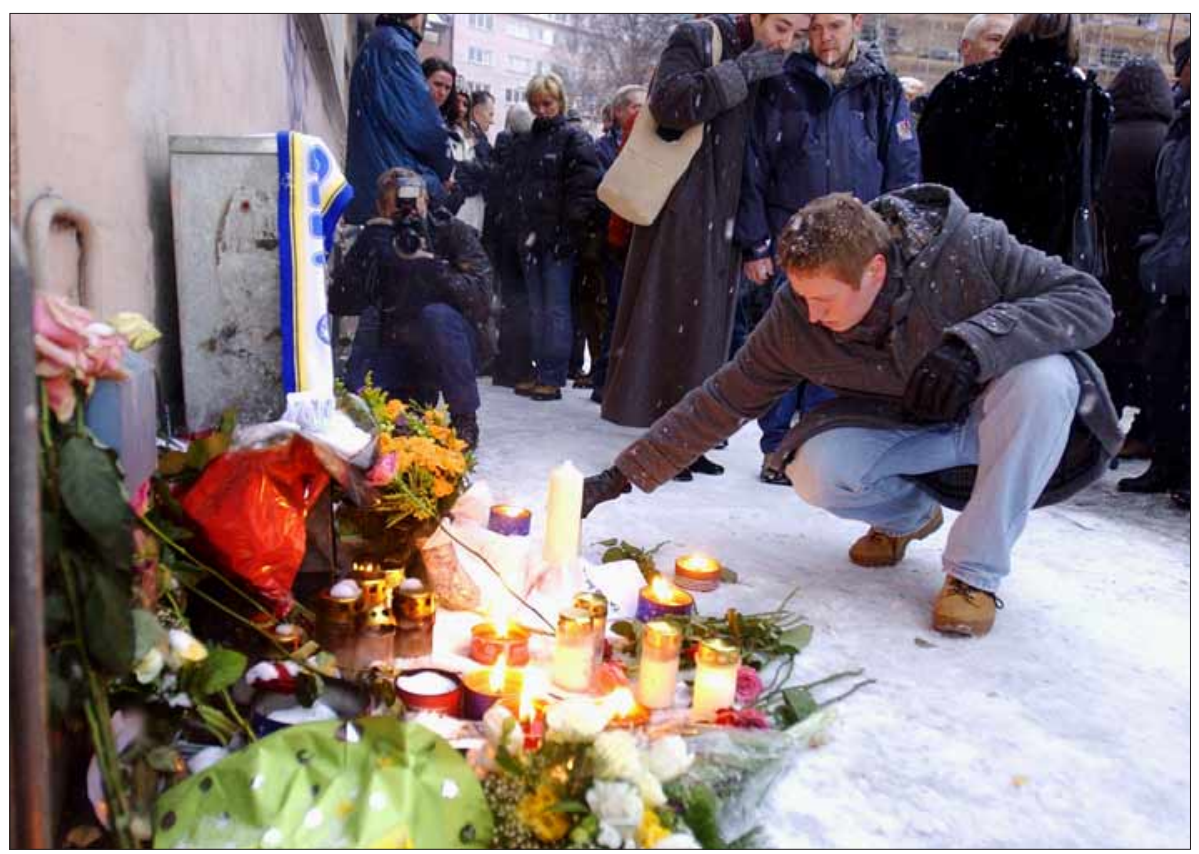

Figure 6. Many young friends assembled at the site of murder when a young man, 23 years old, was killed outside his home in Oslo in 2002. Photo by Truls Brekke, Dagbladet, Oslo. 
sage expressed by the ceremony was for a complete repudiation of all crimes of violence. In situations involving sudden crisis and shock, whether on the national or local level, public expressions of solidarity and repudiation are of vital importance. In these cases, crimes of violence are considered to be symptoms of negative social phenomena as symbolized by video violence, reduction of psychiatric services, etc. A resolve to combat such evils and work for the common good must be developed for the future.

Both Norwegian and Swedish newspapers have published many articles concerning such ritual expressions in recent years. The essential elements are flowers, lit candles, handwritten texts, a silent group of people at the murder site and sometimes a photograph of the victim. At larger gatherings in some public place, sacred or secular, speeches with concluding appeals are also common, expressing a need not only for an appeasement of remembrance and grief, but also for changes with regard to the future (Fig. 6). Anxiety over a resurge of violence can often be expressed at such gatherings if the murderer has not yet been arrested. A demonstration of this kind took place in Oslo in January 2002. The torchlight procession that followed was held under a banner proclaiming "This must not be repeated" (Dagbladet 2002a).

A new form of ritual expression encountered in recent years is that gatherings take place not only immediately after a murder, an accident or other sudden death, but also on the anniversaries of such events. This is especially true of the gathering of friends of the victim(s) on the tragedy's first anniversary. These first anniversaries have attained a special symbolical meaning. For the next of kin, such manifestations by their friends and acquaintances have come to provide very real assistance in the prolonged process of grief. These friends show that they have not forgotten the shocking event, but want to express their feelings once again in a repeated public action. It feels as if the meeting can support us throughout this day of death, the mother of a strangled girl said on the anniversary of her murder in Gothenburg on 19 January 2003. Her friends held a memorial meeting on 19 January 2004 at the same place they had assembled a year before (Göteborgs Tidningen 2004). In other cases, friends of the murder victim have gathered together and placed lit candles, flowers, pictures of angels, red hearts and handwritten notes on the grave.

A more recent way of commemorating the scene of a murder is to put up a memorial stone. This was done after the murder of two policemen on 28 May 1999 in the village of Malexander in Östergötland. The mother of one of the policemen took the initiative for erecting the stone. It was consecrated in October 1999 in the presence of some fifty relatives and friends. During this consecration ceremony, the mother looked towards the future and said, I hope that this memorial will awaken memories, that many people will see it and will 
remember what happened (Göteborgs Posten 1999b). The memorial stone points both back in time to the event and ahead as a protest against future violence. Passers-by have continued to place flowers at the stone.

\section{CONCLUDING REMARKS}

This paper has focused on the types of action and behavioural patterns that emerge among the next of kin and friends when confronted by unexpected death. In such deeply tragic circumstances ritual demonstrations can be of great value by enabling the emotional survival of the victim's next of kin. Activities that the mourners participate in together on recurring occasions can help to alleviate states of shock. The focus of the paper has been on the emergence of numerous innovations having to do with coping with sudden grief in recent years. Special patterns of behaviour have then become evident, such as the use of the Internet to demonstrate grief and remembrance.

Examples of innovation and change of this kind have been emphasized in the study. The public marking of sudden death by means of collective actions has become far more prominent in recent years in comparison to past times. This can be seen at sites where a traffic accident, a murder or manslaughter has occurred, and in connection with memorials to fishermen who have lost their lives at sea.

Commemoration of deaths in traffic accidents and due to murder or manslaughter seems to have assumed similar features in Norway and Sweden in recent years. A behavioural pattern having mostly to do with young people who have perished or been killed has obviously been the subject of fairly rapid cultivation. Compared to previous years, a change is very marked. Young people have seized the initiative in these new rituals concerning traffic accidents, murder or manslaughter but not in connection with memorials to the deceased fishermen. In the latter case, it is the adults who also look after local oral tradition and have taken the initiative.

Fatal accidents involving the young or the middle-aged in recent years are being commemorated in an entirely different manner than those striking the elderly. The tragedy is experienced as being extra tragic when children and young people are the victims. A generational gap is obvious in such incidents. Memorial commemorations are conducted by those belonging to the same age group as the deceased. The youth thus become the centre of attention in that they are the most active and inventive. They express their feelings of grief, loss and solidarity through their actions and by using the Internet. They uti- 
lize visual symbolic expressions such as placing flowers, writing letters or lighting candles. The young find performing these activities in the company of others appropriate. This way much of the anguish connected with sudden death is alleviated and replaced with something of a brighter aspect. This is especially obvious when the young victims are described as being angels in heaven in Internet messages, in keeping with neoreligious views. At the same time the participants demonstrate their solidarity with those who have been hit the hardest - the closest family and relatives.

There is no doubt that newspapers, especially tabloids in Sweden, have been instrumental in the spread of these new rituals commemorating young victims of unexpected death, with their articles and photographs from the scenes of traffic accidents or murders. This is done in a far more obtrusive manner than ever before. Newspaper readers receive impulses which may be acted upon when new accidents are experienced in the future. Newspaper journalists have themselves witnessed the growth of new rituals for which young people have taken the initiative. Such collective actions are then repeated on later occasions, becoming definite behavioural patterns which are adjusted to suit new situations. Newspapers seek to publish such episodes even if journalists are met with reactions of ethical nature from the young people, such as Can't you understand that we're holding a memorial? (Dagbladet 2005). The journalists, however, are not deterred, but take pictures of anything even if the scenes are emotionally charged. As a journalist wrote in Dagbladet on 25 July 2005, [t] he photographers just wait until groups of the bereaved gather together so they can get a shot of "collective sorrow". Nothing of this kind has been experienced in former times. The boundaries of journalistic ethics have evidently been extended in an unmistakable way. A grief-stricken observance for a closed circle of family and friends becomes exposed to the general public in far/distant localities because of the intrusive activities of the press. The newspapers do not construct new rituals, but their intimate reports on them contribute to their spread.

Death in our time has obviously become less secretive and private than was the case in the early 1900s. This is even more obvious in situations of dramatic crisis. The newspapers' clearly increasing interest in life's tragic occurrences has led to a noticeable change in attitude which indicates that such tragedy no longer must be kept secret. It can instead be commemorated more openly in public and in company of one's social group. This is a source for the establishment of new rituals on similar occasions. Feelings of grief and shock affecting young people are expressed more openly in a manner that had never occurred before the 1990s. It is important that the family and friends are able to find 
ways in which to endure the unexpected and appalling. Great benefits can be derived from these manifestations of interdependence and collectivity which can be repeated later in analogous situations. This aids the family and friends by showing that they are not left alone in their shock and grief, but have a clearly expressed network of social support instead. The private sphere has become increasingly public with newspapers becoming important actors. This is a precondition for the formation and later continuation of collective and public patterns of behaviour. Such actions must be observable in a social setting. Solidarity and collectivism have become important key words in the approach to traumatic situations at the expense of individuality and privacy. This is a major innovation in the study of rituals around sudden death in recent times.

While I was working on this paper, the catastrophic earthquake and tidal wave occurred in Southeast Asia on Boxing Day 2004. A discussion of the grief and shock occasioned by this catastrophe, which also affected many Scandinavians, cannot be included in this study, but should instead be analyzed in a special survey. From the historical perspective, a phenomenon of this kind is extremely unusual in Scandinavia. International tourism suddenly acquired a new national and deeply traumatic expression in Scandinavia because of this catastrophe. It also seems to have led to a strengthening of solidarity and collective manifestations of grief in comparison to former ages.

The abovesaid could teach us that ritual expression is subject to continuous revision. Culture is not static but acquires new forms of expression and adapts itself to new situations in keeping with the spirit of the times. Tradition and renewal thus go hand in hand and supplement each other.

\section{REFERENCES}

Aftenposten 2000a = Aftenposten 2000, 26 March, Oslo.

Aftenposten $2000 \mathrm{~b}=$ Aftenposten 2000, 12 August, Oslo.

Aftenposten 2001. 10 November, Oslo.

Aftonbladet 2003. 8 December, Stockholm.

Alver, Bente Gullveig 1996. Det genvundne paradis. Tradisjon.

Alver, Bente Gullveig 1999. Fra englevagt til englevinger. In: Bente Gulleveig Alver et al. (eds.) Myte, magi og mirakel i møte med det moderne. Oslo.

Ariès, Phillippe 1978. Döden. Föreställningar och seder $i$ Västerlandet från medeltiden till våra dagar. Transl. into Swedish by Erik Nyblom, Stockholm. Original: Ariès, 
Phillippe 1975. Western Attitudes toward Death: From the Middle Ages to the Present. The Johns Hopkins University Press.

Bauman, Zygmunt 1994. Döden och odödligheten $i$ det moderna samhället. Transl. into Swedish by Sven-Erik Thorhell. Göteborg. Original: Zygmunt Bauman 1992. Mortality, Immortality, and Other Life Strategies. Stanford University Press.

Bohusläningen 1993. 22 May, Uddevalla.

Bohusläningen 1994. 30 July, Uddevalla.

Bohusläningen 2002. 30 July, Uddevalla.

Bringéus, Nils-Arvid 1988. Pictures of the Life Cycle. Ethnologia Scandinavica, Vol. 18 , pp. 5-32.

Dagbladet 2002a. 26 January, Oslo.

Dagbladet 2002b. 12 August, Oslo.

Dagbladet 2005. 25 July, Oslo.

Dahlgren, Curt 2000. När döden skiljer oss åt... Anonymitet och individualisering $i$ dödsannonser: 1945-1999. Lund: Teologiska institutionen, Univ.

Fulsås, Narve 2003. Havet, døden og veret. Kulturell modernisering i Kyst-Noreg 1850-1950. Oslo: Det Norske Samlaget.

Guestbook (n.d.). Website at www.johanne-rip.com, not available.

Gustavsson, Anders 1984. Pingströrelsen på Åstol. Processen från minoritet till dominerande lokal kultur. Lund: Signum.

Gustavsson, Anders 2003. Gravstenar i Norge och Sverige som symboler för känslor, tankar och idéer $i$ vår egen tid. En tilltagande individualitet under 1990-talet? Oslo: Novus.

Göteborgs Posten 1996. 2 January, Göteborg.

Göteborgs Posten 1999a. 17 January, Göteborg.

Göteborgs Posten 1999b. 24 October, Göteborg.

Göteborgs Tidningen 2003. 21 September, Göteborg.

Göteborgs Tidningen 2004. 19 January, Göteborg.

Göteborgs Tidningen 2005. 31 January, Göteborg.

Halden Arbeiderblad 2003. 25 November, Halden.

Klein, Barbro 1995. Inledning. Gatan är vår! Ritualer på offentliga platser. Barbro Klein (ed.). Stockholm: Carlsson.

af Klintberg, Bengt 1973. Gasten i svensk folktradition. Stockholm: Institutet för Folklivsforskning.

Kyrkans Tidning 2003. 30 October-5 November, Stockholm.

Köstlin, Konrad 1999. Roadside Memorials. The Cross in European Culture. In: Gustavsson, Anders \& Maria Santa Vieira Montez (eds.). Folk Religion. Continuity and Change. Lisboa \& Uppsala: Instituto de Sociologia e Etnologia das Religioes, Universidade Nova de Lisboa and Etnologiska Institutionen Uppsala Universitet.

Pentikäinen, Juha 1974. De döda utan status. Stockholm: Insitutet for Folklivsforskning.

Scharfe, Martin 1989. Totengedenken. Zur Historizität von Brauchtraditionen. Das Beispiel Olof Palme 1986. Ethnologia Scandinavica.Vol. 19, pp. 142-153.

VG 2000 = Verdens Gang 2000. 8 February, Oslo. 
VG 2004 = Verdens Gang 2004. 2 December, Oslo.

Åberg, Georg \& Edvardsson, Dag 1985. Dom hade inget val. De västsvenska fiskarna under krigsåren 1939-1945. Uddevalla: Bohusläns museum and Bohusläns hembygdsförbund.

Åkesson, Lynn 1997. Mellan levande och döda. Föreställningar om kropp och ritual. Stockholm: FRN. 